УДК: 621.398 .624

\author{
V.V. Chikovani
}

National aviation university, Kyiv

\title{
INFLUENCE OF EXTERNAL SHOCKS AND INTERNAL NOISES ON THE RESONANT FREQUENCY TRACKING SYSTEM IN CORIOLIS VIBRATORY GYROSCOPE
}

Resonant frequency tracking system that ensures rapid capture and track of frequency when switching on the gyro at any temperature from the working temperature range in Coriolis vibratory gyro are proposed and analyzed in this work. The problems of external shocks and internal noises influence suppression on the performance of resonant frequency tracking system, built on the basis of phase lock loop by tuning PIDF controller coefficients, used in feedback control loop of the tracking system are investigated.

Key words: Coriolis vibratory gyroscope, phase lock loop, voltage control generator, linearization.

\section{Introduction}

In order to obtain highest accuracy and sensitivity of Coriolis vibratory gyroscope (CVG) its resonator should be excited at the resonant frequency. However, in the process of CVG operation the resonant frequency changes because of temperature and other effects. The resonant frequency changes require development of tracking system so that excitation signal would have the resonant frequency at the moment of its applying on the resonator. One of such system is autogenerator, the positive feedback loop tuning such that total amplification coefficient of the loop is equal to unity and total phase is zero. Such a system finds the resonant frequency very quickly and tracks it at its temperature variations [1]. The autogenerator disadvantage is high tracking noise, therefore, other resonant frequency tracking systems are used for precision devices. One of the most frequently used systems is phase lock loop (PLL) [2]. PLL disadvantage in application to CVG is that for rapid and reliable "capture" of the resonant frequency that defines CVG start-up time, which should be minimal (0.1-1) s for modern gyros, the frequency initial value should be indicated sufficiently close to real resonant frequency. Since the gyro should have minimal start-up time when switching on at any temperature from the range $[-40+85]^{\circ} \mathrm{C}$, then it is very hard to sufficient precisely indicate the real resonant frequency.

CVG resonant frequency tracking system which ensures rapid "capture" and track it when switching on the gyro at any temperature from the operating temperature range is proposed and analyzed in this work. The problems of external shock type disturbances and internal noises which generate buffers, modulator, demodulator, and also ADC and DAC, in case of digital implementation of the system, which undoubtedly is preferable, are investigated.

\section{PLL for CVG block diagram}

PLL block diagram and its connection to CVG sensing element (SE) is presented in fig.1. SE consists of three units: actuator, resonator and sensor. The voltage at the resonant frequency is applied on the actuator to excite oscillations. The resonator is a metallic cylinder, in which there is a standing wave on the second elliptical mode of vibration with four antinodes and four nodes. There appears oscillations in nodes with amplitude proportional to angle rate when the cylinder is rotating around its axis of symmetry, at this resonant frequency is modulated by angle rate [3]. Sensor measures this oscillations amplitude. Flat piezoceramic electrodes are used as actuator and sensor in real CVG.

PLL consists of three basic units: phase detector (PD), which is realized as an amplitude demodulator consisting of multiplier and low pass filter (LPF),

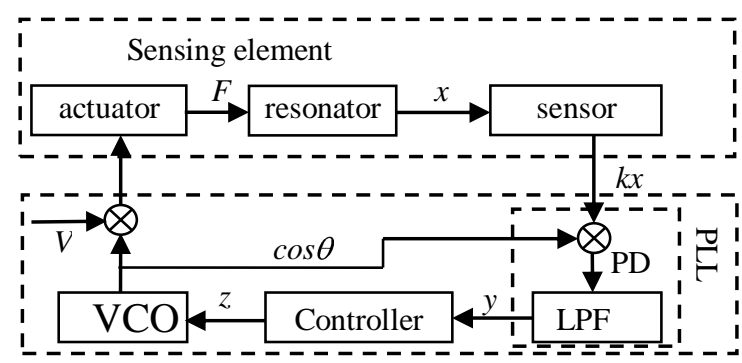

Fig. 1. PLL and SE connection block diagram

controller, which is realized as proportional-integraldifferential (PID) regulator and voltage control oscillator (VCO). PLL is connected from one side to the actuator 
located at the one untinode and from another side to the sensor located at the other untinode.

Resonator oscillation dynamic can be described by the following second order differential equation:

$$
\ddot{x}+\frac{\omega_{r}}{Q} \dot{x}+\omega_{r}^{2} x=F,
$$

where $x$ is the resonator deviation from its neutral position, $Q$ is the resonator's quality factor, $\omega_{r}$ is resonant frequency, $F$ is excitation force, applied from the actuator. This force $F$ can be represented as:

$$
\begin{gathered}
F=A \cos \theta=A \cos \left(\omega_{r} t+\varphi\right) ; \\
A=V^{*} w / g_{31},
\end{gathered}
$$

where $\theta$ is $\mathrm{VCO}$ instantaneous phase, $\cos \theta$ is $\mathrm{VCO}$ output signal, $A$ - force amplitude, determined by piezoceramic parameters and oscillation amplitude $V$ set by CVG amplitude stabilization system, $w$ is piezoelectrode's width, $g_{31}$ is piezoelectric voltage constant [4].

The sensor output signal $x$ is proportional to mechanical oscillation amplitude with proportionality coefficient $k=t /\left(L d_{31}\right)$, where $t, L$ are the piezoelectric plate's thickness and length, respectively, $d_{31}$ is piezoelectric strain constant [4].

PD output signal is determined by the following relationship:

$$
\dot{y}=\lambda \ll x \cos \theta-y^{\prime},
$$

where $\lambda$ is LPF cutting frequency. PID controller output signal $\mathrm{z}$ is:

$$
z=K_{I} \int_{0}^{t} y d \tau+K_{p} y+K_{d} \dot{y}
$$

or

$$
\dot{z}=K_{I} y+K_{p} \dot{y}+K_{d} \ddot{y} \text {. }
$$

Instantaneous frequency on the VCO output is described by the equation:

or

$$
\omega \equiv \dot{\theta}=\omega_{0}+K_{V C O} z
$$

$$
\theta=\int_{0}^{t} \omega_{0}+K_{V C O} z d \tau
$$

where $\omega_{0}$ is VCO initial frequency, $K_{V C O}$ is VCO transformation coefficient which dimension is $\mathrm{Hz} / \mathrm{V}$.

$\mathrm{VCO}$ control voltage is determined by integral of the controller signal:

$$
u=\cos \theta=K_{V C O} \int_{0}^{t} z d \tau
$$

or

$$
\dot{u}=K_{V C O} z
$$

As a result the system of differential equations which describe PLL operation in CVG can be obtained:

$$
\begin{gathered}
\ddot{x}+\frac{\omega_{r}}{Q} \dot{x}+\omega_{r}^{2} x=F \\
\dot{\theta}=\omega_{0}+K_{V C O} z \\
\dot{z}=K_{I} y+K_{p} \dot{y}+K_{d} \ddot{y} \\
\dot{y}=\lambda<x \cos \theta-y_{-} .
\end{gathered}
$$

These equations are nonlinear ones relative to $\theta$ variable and it is difficult to analyze them. Stability analysis for such nonlinear system is presented in [2]. It should be noted that PLL ensures resonant frequency "capture" if its initial frequency $\omega_{0}$ is sufficiently close to resonant one $\omega_{r}$. Taking into account that $\omega_{r}$ is global maximum, then the closer the initial frequency to global maximum, the more reliable and rapid the resonant frequency will be "captured" by PLL. Moreover, under condition of proximity of $\omega_{0}$ to $\omega_{r}$ PLL parameters can be tuned to narrow band of frequency "capture" minimizing the PLL noise, and, therefore, tracking accuracy can be increased.

One of the possible and effective techniques to set PLL initial frequency when switching CVG at any temperature from the range $-40+85^{\circ} \mathrm{C}$ is to insert in the tracking system the next auxiliary units: autogenerator, frequency meter and switcher as shown in fig.2. In the process of autogenerator operation, frequency meter determines the resonant frequency.

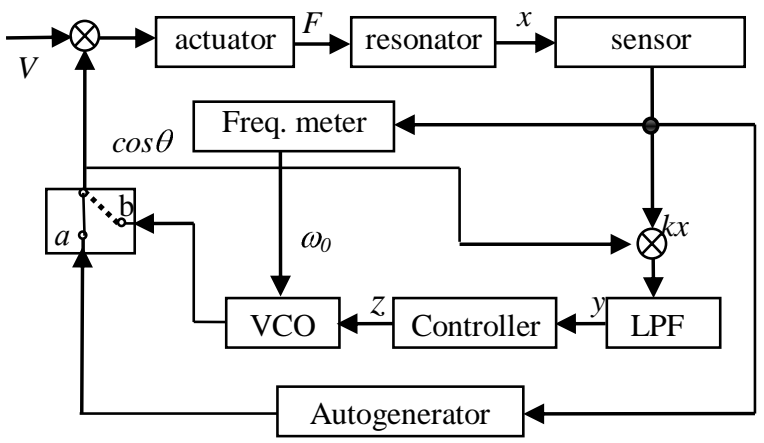

Fig.2. PLL block diagram with autogenerator

For 200-500 resonant frequency periods (50-100 $\mathrm{ms}), 0.1-0.2 \mathrm{~Hz}$ measurement error can be obtained. It is enough for PLL to capture the frequency as rapid as possible after switching the signal from autogenerator (switcher position $a$ ) to PLL (switcher position $b$ ) and to continue tracking with low noise. Doing this, total startup time will be in the range 0.1-1 s. PLL bandwidth and transient process are mainly defined by the PLL controller parameters $K_{I}, K_{p}$ and $K_{d}$.

\section{PLL linearization}

When PLL operates in the vicinity of resonant frequency it can be described by linearized equations to a sufficient high accuracy. So, PLL linearized transfer function should be obtained. Firstly, it should be noted that linearized SE transfer function when it operates in 
the vicinity of resonant frequency together with demodulator can be presented as follows [1]:

$$
H=\frac{Q P_{0}}{\omega_{r}^{2}} \frac{1}{\frac{2 Q}{\omega_{r}} s+1},
$$

where $P_{0}$ is SE amplification coefficient at resonant frequency. In this case the tracking system block diagram is reduced to the view presented in fig. 3 .

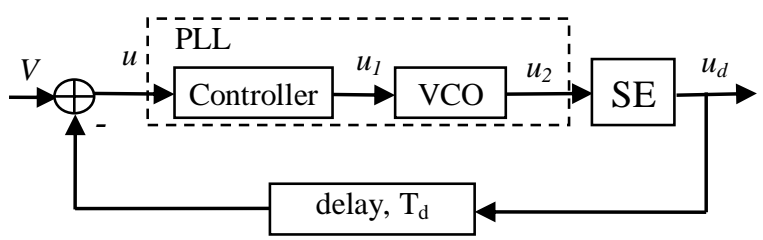

Fig. 3. Tracking system reduced block diagram

Here delay was introduced to take into account demodulator dynamics, containing LPF which defines time delay $\mathrm{Td}$ depending on filter's order.

SE output signal can be written down as follows:

$$
u_{d}(t)=\sin \left[\varphi_{1}(t)-\varphi_{2}(t)\right],
$$

where $\varphi_{1}, \varphi_{2}$ are $\mathrm{SE}$ and $\mathrm{VCO}$ output signal instantaneous phases, respectively.

When phase difference $\Delta \varphi=\varphi_{1}-\varphi_{2} \ll \pi / 2$ one can write:

$$
u_{d}(t)=\left[\varphi_{1}(t)-\varphi_{2}(t)\right]=\Delta \varphi .
$$

Having designated the controller transfer function as $F(s)$, its equation in Laplace transform can be written down as follows:

$$
u_{l}(s)=F(s) u(s) .
$$

PLL basic equation is defined by the VCO and is as follows:

$$
u_{2} \uparrow=\omega_{0}+K_{V C O} \int_{d_{1}}^{t_{2}} u_{1} \propto d t .
$$

All these equation is valid when PLL operates in stationary mode at the resonant or close to it frequency.

Having designated Laplace transform of PLL signals $u(t)$ and $u_{2}(t)$ as $u(s)$ and $u_{2}(s)$ for linearized transfer function of PLL (without phase detector which has been inserted in SE as demodulator) can be obtained:

$$
G=\frac{u_{2}}{u}=\frac{K_{V C O} F}{s} .
$$

Let's consider proportional-integral-differential with low pass filter (PIDF) to smooth the differentiator noise as a controller with the following transfer function:

$$
\begin{aligned}
& F=\frac{K_{d} N s}{s+N}+K_{p}+\frac{K_{i}}{s}= \\
& =\frac{\boldsymbol{K}_{p}+N K_{d}^{2} s^{2}+\boldsymbol{k}_{p} N+K_{i} \underline{s}+N K_{i}}{s^{2}+N s},
\end{aligned}
$$

where $K_{d}, K_{p}, K_{i}$ are differential, proportional and integral chain coefficients, respectively, $N$ is the low pass filter pole. In this case transfer function of linearized PLL takes the following view:

$$
G=\frac{\left(\boldsymbol{k}_{p}+N K_{d}{ }^{2} s^{2}+\boldsymbol{k}_{p} N+K_{i} \underline{s}+N K_{i}\right.}{s^{2}+N s} \frac{K_{V C O}}{s} .
$$

Now, the resonant frequency tracking system block diagram can be presented as follows (fig.4):

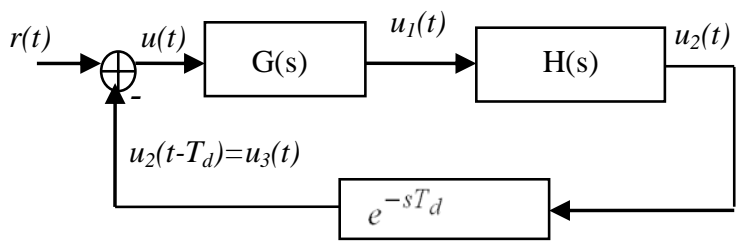

Fig.4. Linearized tracking system block diagram

\section{Influence of shock type disturbance}

External shock type disturbance $b(t)$ is introduced on the SE output as shown in fig.5.

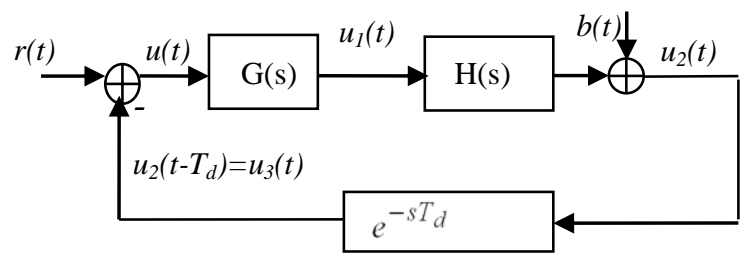

Fig.5. Tracking system block diagram with shock disturbance

Disturbance transfer function $A_{b}(s)$ is defined by the following expression:

$$
\begin{gathered}
A_{b}=\frac{U_{2}}{B}=\frac{1}{1+H G D}= \\
=\frac{s^{2}\left(\frac{2 Q}{\omega_{r}} s^{2}+\left(N \frac{2 Q}{\omega_{r}}+1\right) s+1\right)}{\left[\frac{2 Q}{\omega_{r}} s^{4}+\left(N \frac{2 Q}{\omega_{r}}+1\right) s^{3}+N+K_{p}+N K_{d} \stackrel{\vec{s}}{2}^{2}+K_{p} N+K_{i} \underline{s}+K_{i} N\right] \frac{Q P_{0}}{\omega_{r}^{2}} K_{V C O e^{-s T_{d}}}},
\end{gathered}
$$

where $D(s)=e^{-s T_{d}}$. At phase step of $\beta$, transfer function of the step is $\beta / \mathrm{s}$, and total angle measurement error, taking into account Laplace transform properties, is equal to:

$$
\lim _{s \rightarrow 0} \frac{v A B}{s}=\lim _{s \rightarrow 0} \frac{v A \underline{\beta}}{s^{2}}=\frac{v \beta}{K_{V C O} K_{i} \frac{Q P_{0}}{\omega_{r}^{2}}} .
$$

Coefficient $v$ characterizes sensitivity of frequency change to angle rate measurement. Let's set maximum angle measurement error equal to $E_{\max }=0.1 \mathrm{arc} \min$ $\left(2.9 * 10^{-5} \mathrm{rad}\right.$.), then the following inequality should be valid:

$$
\begin{gathered}
\frac{v \beta}{K_{\Gamma У H} K_{i} \frac{Q P_{0}}{\omega_{r}^{2}}} \leq E_{\max } \rightarrow K_{i} \geq \frac{v \beta}{K_{V C O} E_{\max } \frac{Q P_{0}}{\omega_{r}^{2}}}= \\
=\frac{2 * 10^{-4} * 0.1}{10 * 2.9 * 10^{-5} * 0.5} \approx 0.14
\end{gathered}
$$


At numerical calculations the following values were set $\beta=0.1 \mathrm{rad}$., $\mathrm{K}_{\mathrm{VCO}}=10 \mathrm{~Hz} / \mathrm{V}$. Thus for phase step of $\beta=0.1 \mathrm{rad}$. angle measurement error will be no more than 0.1 arc min when amplification coefficient of PIDF controller integrating chain is $K_{i}>0.14$. Such high accuracy is due to low sensitivity of angle rate measurement error to resonant frequency change $v=2 * 10^{-4}$.

Disturbance amplitude-frequency characteristic (AFC) of the tracking system is presented in fig.6.

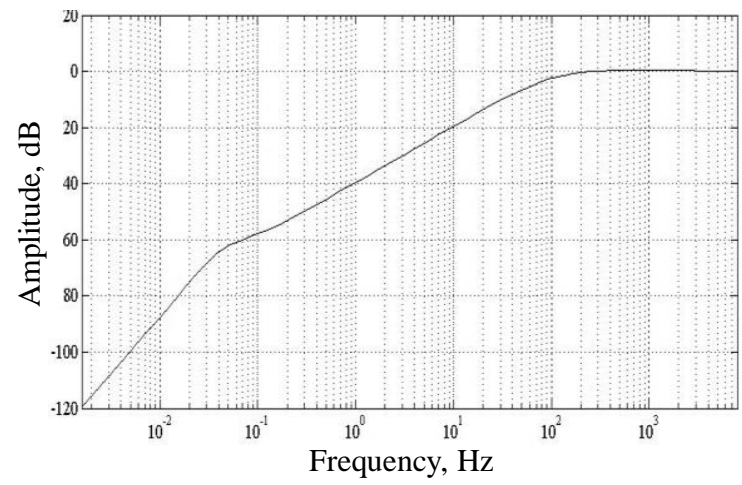

Fig.6. Disturbance AFC of the tracking system

This figure shows that external shock type disturbance suppression bandwidth, for controller coefficients: $K_{d}=95, K_{p}=498, K_{i}=578, N=22738$ spread up to 100 $150 \mathrm{~Hz}$.

Unit step response is presented in fig.7. It shows that system settling time is $60 \mathrm{~ms}$.

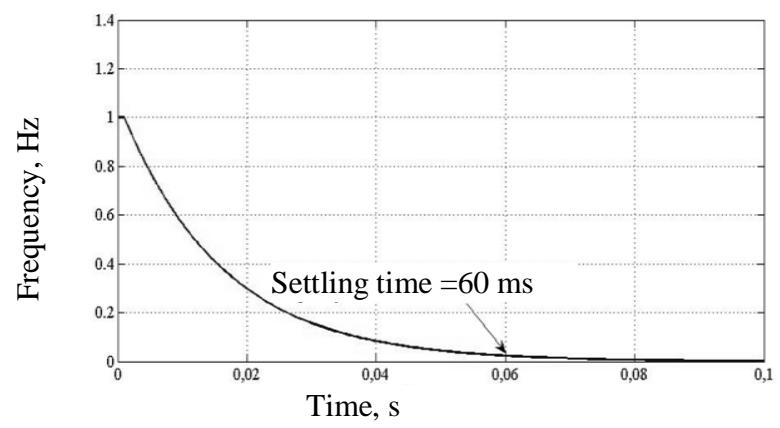

Fig. 7. Frequency tracking system settling time after shock

It is clear that if the disturbance suppression bandwidth is $100-150 \mathrm{~Hz}$, then the same bandwidth of the useful signal will be passed. Let's show that at the same controller parameters the tracking system bandwidth on input-output $\left(r(t) \rightarrow u_{2}(t)\right)$ is about $100 \mathrm{~Hz}$. For this let's write input-output transfer function as follows:

$$
\begin{aligned}
& A_{R}=\frac{U_{2}}{R}=\frac{G H}{1+H(G)}= \\
& \mathbf{k}_{p}+N K_{d} \bar{s}^{2}+\boldsymbol{k}_{p} N+K_{i} \bar{S}+K_{i} N \frac{-Q P_{0}}{-\omega_{r}^{2}} K_{V C O} \\
& =\overline{\left[\frac{2 Q}{\omega_{r}} s^{4}+\left(N \frac{2 Q}{\omega_{r}}+1\right) s^{3}+\mathbf{N}+\boldsymbol{k}_{p}+N K_{d} \overline{\underline{s}}^{2}+\boldsymbol{k}_{p} N+K_{i} \vec{S}+K_{i} N\right] \frac{Q P_{0}}{\omega_{r}^{2}} K_{V C O} e^{-s T_{d}}},
\end{aligned}
$$

Fig. 8 presents input-output AFC of the tracking

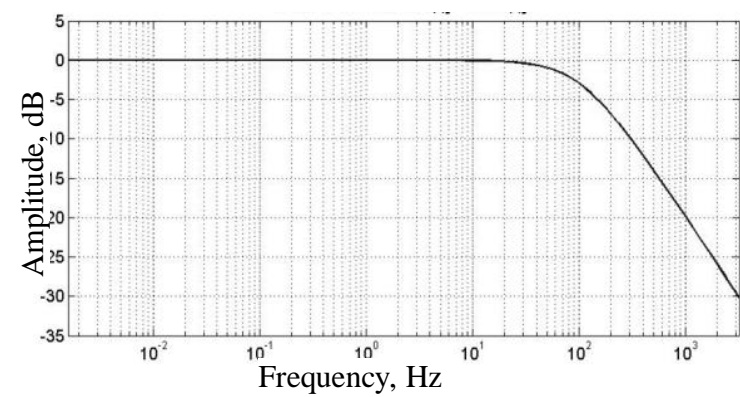

Fig.8. The tracking system bandwidth

system. This figure shows that tracking system bandwidth on the input (useful) signal is $100 \mathrm{~Hz}$.

\section{Influence of noises}

The noises $w_{d}(t)$ of demodulator, output buffer, and in case of digital implementation of the system, analog-to-digital converter (ADC) are inserted in the system after delay chain as shown in fig.9.

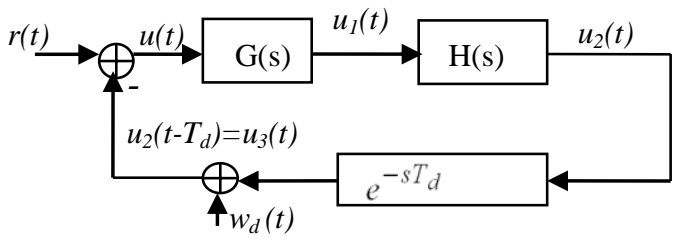

Fig.9. Block diagram with $w_{d}(t)$ noise

Transfer function by the inserted noise can be written down as follows:

$$
\begin{aligned}
& A_{w_{d}}=\frac{U_{2}}{W_{d}}=-\frac{G H}{1+G H}=
\end{aligned}
$$

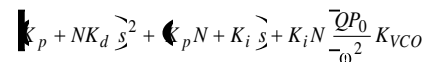

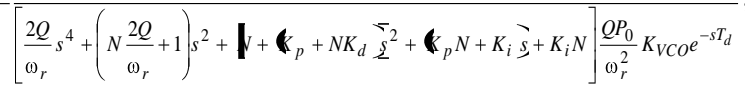

This system AFC is presented in fig. 10 .

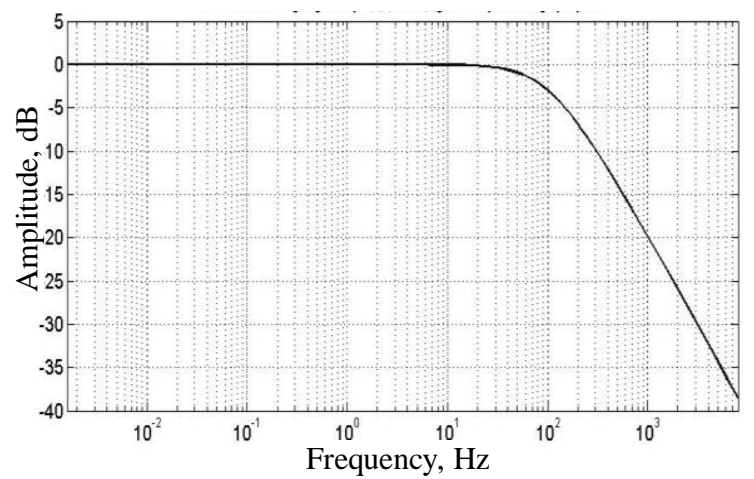

Fig.10. Noise $w_{d}(t)$ suppression

This figure shows that high frequency noise is only suppressed. Noise $w_{d}(t)$ sources have high frequency character. So, demodulator operates at the resonant 
frequency (4-5 kHz), and ADC at about $100 \mathrm{kHz}$. Intensities of these noises are concentrated at the frequencies of their operation and, therefore, are effectively suppressed by the system.

The noises $w_{m}(t)$ of modulator, input buffer, and in case of digital implementation of the system, digital-toanalog converter (DAC) are inserted in the system before SE as shown in fig. 11.

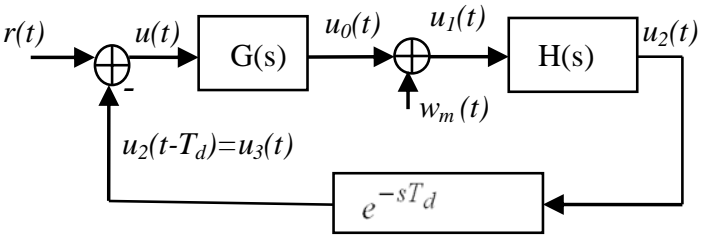

Fig.11. Block diagram with $\boldsymbol{w}_{m}(t)$ noise

Transfer function of the tracking system by inserted noise is:

$$
\begin{aligned}
& A_{w_{m}}=\frac{U_{2}}{W_{d}}=\frac{H}{1+G H D}= \\
& =-\frac{s^{2}+N \frac{Q P_{0}}{\omega_{r}^{2}}}{\left[\frac{2 Q}{\omega_{r}} s^{4}+\left(N \frac{2 Q}{\omega_{r}}+1\right) s^{2}+\mathbf{V}+\boldsymbol{K}_{p}+N K_{d} \underset{\underline{s}^{2}}{\stackrel{2}{2}} \boldsymbol{(}_{p} N+K_{i} s+K_{i} N\right] \frac{Q P_{0}}{\omega_{r}^{2}} K_{V C O} e^{-s T_{d}}},
\end{aligned}
$$

Transfer function $A_{w_{m}}$ AFC is presented in fig. 12 .

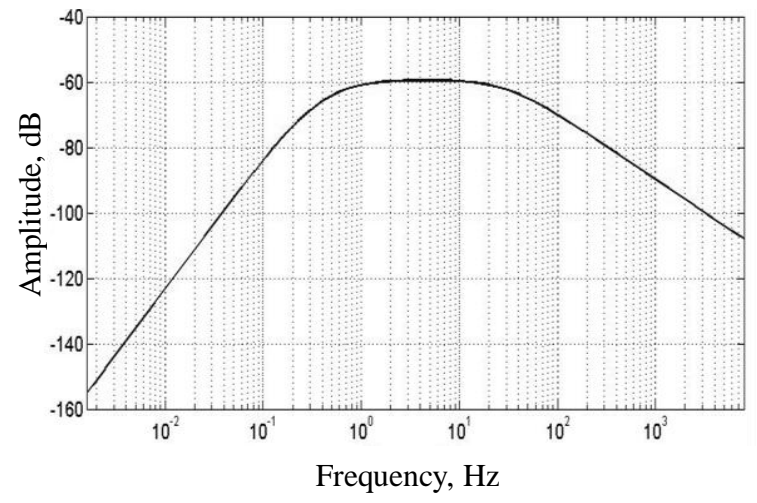

Fig.12. Noises $w_{m}(t)$ suppression

Fig.12 shows that the tracking system provides suppression of no less than $60 \mathrm{~dB}$ over all frequency range, but in the range less than $0.5 \mathrm{~Hz}$ and more than $50 \mathrm{~Hz}$ suppression is more significant.

\section{Tracking system accuracy analysis}

Resonant frequency searching time depends on how close to it is set PLL initial frequency $\omega_{0}=2 \pi f_{0}$. The closer the initial frequency to the resonant one, the more rapid and accurate the PLL finds it. Fig.13 shows the dependence of frequency difference $f_{r}-f_{V C O}$ between resonant frequency $f_{r}$ and excitation frequency $f_{V C O}$ coming from the VCO at $f_{0}=0$.

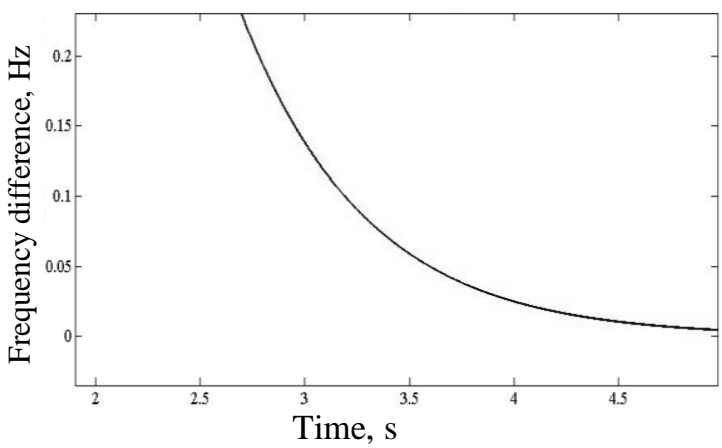

Fig. 13. Resonant frequency searching process at $f_{0}=\mathbf{0}$

VCO excitation frequency reaches up resonant one to an accuracy of $0.01 \mathrm{~Hz}$ for $4.5 \mathrm{~s}$.

Fig.14 shows the same dependence when VCO initial frequency is $f_{0}=f_{r}-0.5 \mathrm{~Hz}$.

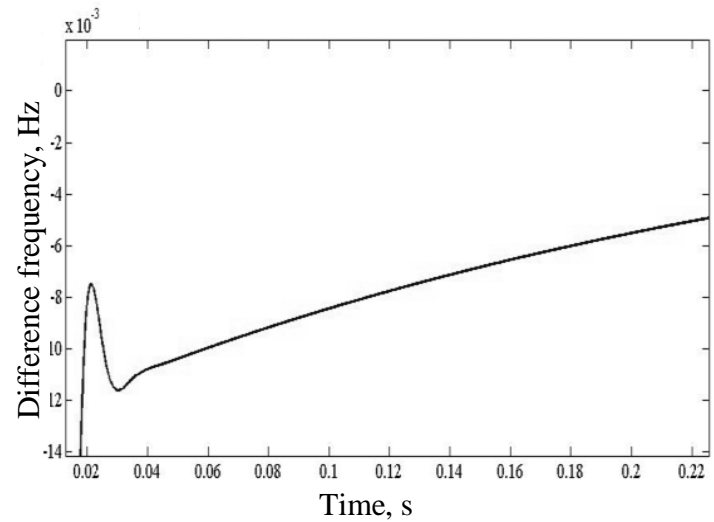

Fig.14. Resonant frequency searching process at $f_{0}=f_{r}-0.5 \Gamma u$

As can be seen from the figure in $20 \mathrm{~ms}$ the difference between excitation frequency and resonant one becomes less than $0.01 \mathrm{~Hz}$. Thus in order to rapid capture resonant frequency by PLL it needs to launch autogenerator, then to measure resonant frequency by frequency meter and then to switch excitation to PLL setting VCO initial frequency to an accuracy of no less than $0.5 \mathrm{~Hz}$.

Fig. 15 shows graphs of PLL input noise $w_{d}(t)$ with
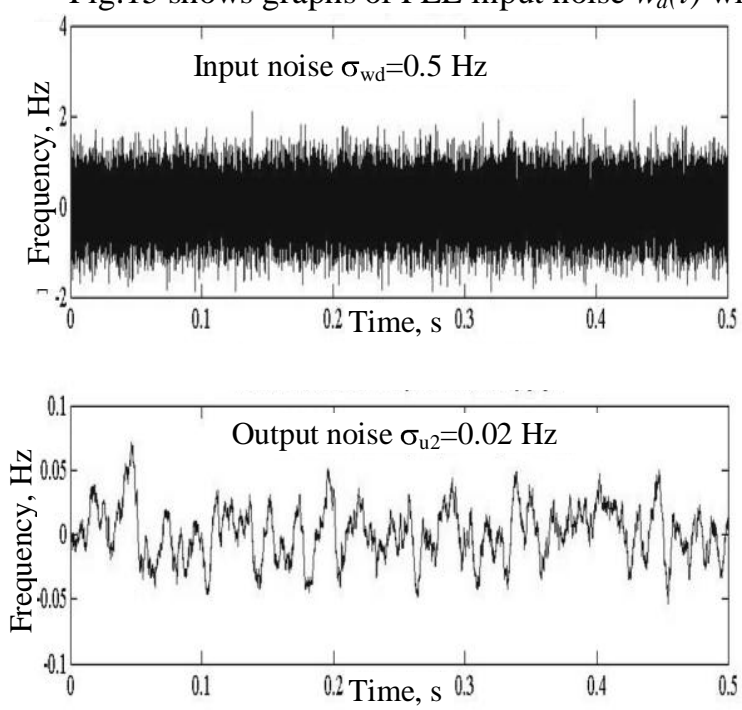

Fig. 15. PLL input noise $\boldsymbol{w}_{d}(t)$ (up) and CVG output noise $u_{2}(t)$ (down) 
root mean square (RMS) value of $\sigma_{w d}=0.5 \mathrm{~Hz}$ in the frequency range up to $50 \mathrm{kHz}$ and $\mathrm{CVG}$ output noise which RMS value is of $\sigma_{u 2}=0.02 \mathrm{~Hz}$. So, suppression coefficient of demodulator, output buffer and ADC noises, $w_{d}(t)$, is equal to $0.5 / 0.02=25 \approx 28 \mathrm{~dB}$.

Fig.16 shows graphs of $\mathrm{CVG}$ output noise with RMS value of $\sigma_{u 2}=2.1 * 10^{-5} \mathrm{~Hz}$ when PLL input noise $w_{m}(t)$ is the same as $w_{d}(t)$ shown in fig. 15 .

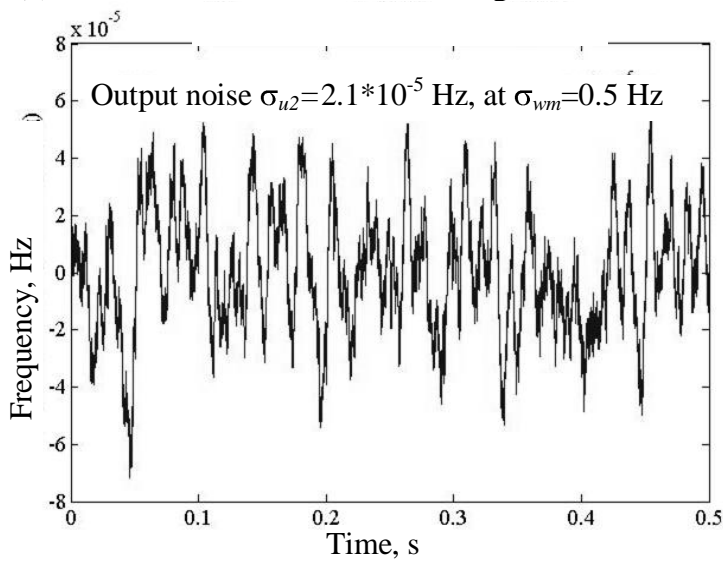

Fig. 16. CVG output noise $\mathbf{u}_{2}(\mathbf{t})$ when PLL input noise $w_{m}(t)=w_{d}(t)$

In this case suppression coefficient of modulator, input buffer and DAC noises $w_{m}(t)$ is $0.5 / 2.1 * 10^{-5} \approx$ $23800 \approx 87 \mathrm{~dB}$, which is many more than suppression coefficient of $w_{d}(t)$ noises. Therefore, special attention should be paid to reduction of demodulator, output buffer and ADC noises minimizing them with the use of circuit technology.

\section{Conclusion}

1. In order to provide short start-up time when switching on the CVG at any temperature from the range $-40+85^{\circ} \mathrm{C}$ it needs to use autogenerator and frequency meter with subsequent transition to PLL to minimize frequency tracking noise.
2. To minimize influence of shock disturbances on the resonant frequency tracking system performance in CVG it needs to use in PLL PIDF controller tuned to bandwidth of $100 \mathrm{~Hz}$. Doing this angle measurement error due to shock disturbance is dependent on amplification coefficient $K_{i}$ of controller integrating chain which can be chosen from angle measurement accuracy requirement.

3. Special attention should be paid to reduce demodulator, output buffer and ADC noises, because suppression coefficient of the other noise sources such as modulator, input buffer and DAC is much more and makes about $87 \mathrm{~dB}$.

\section{References}

1. L. G. Brooks "Amplitude and Frequency Demodulation Controller for MEMS Accelerometer".-- Dissertation Bachelor of Science and Master of Engineering in Computer Science and Engineering, MIT, Feb. 2000, p.122.

2. X. Sun, R. Horowitz, K. Komvopoulos "Stability and Resolution Analysis of a Phase-Locked Loop Natural Frequency Tracking System for MEMS Fatigue Testing”. - Journal of Dynamic Systems, Measurement, and Control, December 2002, Vol. 124, pp.599-605.

3. Матвеев В.А., Лунин Б.С., Бесараб М.А. Навигаџионные системы на волновых твердотельных гироскопах. М.:Физматлит, 2008. - 238 c.

4. Шарапов В.М., Мусиенко М.П., Шарапова Е.В. Пьезокерамические преобразователи физических величин. Черкассы, ЧГТУ, 2005. - 631 c.

Рецензент: д.т.н., проф. А.А. Туник, НАУ, м. Київ.

\section{ВПЛИВ ЗОВНІШНІХ УДАРІВ ТА ВНУТРІШНІХ ШУМІВ НА СИСТЕМУ СТЕЖЕННЯ ЗА ЧАСТОТОЮ У КОРІОЛІСОВОМУ ВІБРАЦЙНОМУ ГІРОСКОПІ}

В.В. Чіковані

У роботі пропонується $і$ аналізується система стеження за резонансною частотою резонатора коріолісового вібраиійного гіроскопа, яка забезпечує швидке захоплення і стеження за частотою при включенні гіроскопа на будь-якій температурі з діапазону робочих температур. Досліджуються питання пригнічення впливу зовнішніх імпульсних дій типу ударів, а також внутрішніх шумів на роботу системи стеження, побудованої на основі системи фазового автопідстроювання частоти, иляхом налаштування параметрів ПИДФ контролера, використовуваного в ланиюзі зворотного зв'язку системи.

Ключові слова: коріолісовий вібрачійний гіроскоп, фазова автопідстрійка частоти, генератор керований напругою, лінеаризачія.

\section{ВЛИЯНИЕ ВНЕШНИХ УДАРОВ И ВНУТРЕННИХ ШУМОВ НА СИСТЕМУ СЛЕЖЕНИЯ ЗА ЧАСТОТОЙ В КОРИОЛИСОВОМ ВИБРАЦИОННОМ ГИРОСКОПЕ}

В.В. Чиковани

В работе предлагается и анализируется система слежения за резонансной частотой резонатора кориолисового вибрачионного гироскопа, которая обеспечивает быстрый захват и слежение за частотой при включении гироскопа на любой температуре из диапазона рабочих температур. Исследуются вопросы подавления влияния внешних импульсных воздействий типа ударов, а также внутренних шумов на работу системы слежения, построенной на основе системы фазовой автоподстройки частоты, путем настройки параметров ПИДФ контроллера, используемого в цепи обратной связи системы слежения.

Ключевые слова: кориолисовый вибраиионный гироскоп, фазовая автоподстройка частоты, генератор управляемый напряжением, линеаризация. 